\title{
Influence of High Light Intensity and Nitrate Deprivation on Growth and Biochemical Composition of the Marine Microalgae Isochrysis galbana
}

\author{
Neha Mishra ${ }^{1}$ \\ https://orcid.org/0000-0001-6931-9544 \\ Sheo Mohan Prasad ${ }^{2}$ \\ https://orcid.org/0000-0003-0207-230X \\ Neetu Mishra ${ }^{3 *}$ \\ https://orcid.org/0000-0002-3146-2465
}

\begin{abstract}
'Sam Higginbottom University of Agriculture, Ethelind Collage of Home Science, India; ${ }^{2}$ University of Allahabad, Department of Botany, Allahabad, India; ${ }^{3}$ University of Allahabad, Department of Home Science, Allahabad, India.
\end{abstract}

Received: 2018.07.29; Accepted: 2019.07.08.

*Correspondence: dr.neetu.au@gmail.com; Tel.: +9807060312 (N.M.)

\section{HIGHLIGHTS}

- Influence of abiotic stress on the biochemical composition of microalgae has considerable physiological and biotechnological importance.

- High light conditions and nitrogen limitations enhanced lipid and carbohydrate productivity in Isochrysis galbana.

- Limitation of nitrogen significantly decreased all photosynthetic pigments, TPC and antioxidant activity.

- These stresses induce significant increase of palmitic, and oleic, acids and decrease polyunsaturated fatty acid except docosahexaenoic acid.

Abstract: Isochrysis galbana is a brown microalgae widely used as a feed for marine organism in aquaculture. The aim of present study is to investigate the growth, biochemical composition, fatty acid profile, photosynthetic parameters and antioxidant activity (radical scavenging activity) of Isochrysis galbana cells cultivated under different levels (sub-optimum; $50 \pm 1.5$,optimum; $125 \pm 2.5$ and supra-optimum; $325 \pm$ $3.5 \mu \mathrm{mol}$ photons $\mathrm{m}-2 \mathrm{~s}-1$ ) of photosynthetic active radiation (PAR), and subsequently treated with different concentration of nitrate deprivation $(8 \mathrm{mM}, 2 \mathrm{mM}$ and $0.5 \mathrm{mM})$. The experiment was carried out under controlled conditions utilizing a factorial design $3 \times 3$ (light intensity and nitrate concentration). The result depicts that PAR positively influences the growth of Isochrysis galbana which is maximum under supra-optimum PAR. Nitrate deprivation $(2 \mathrm{mM} \& 0.5 \mathrm{mM})$ induced decline in growth in terms of dry weight is observed as $60.1 \%$ \& $61.9 \%$ in suboptimum and $26.5 \%$ and $34.9 \%$ in supra- 
optimum respectively over the values recorded in their respective controls. Supraoptimum PAR decreased primary photosynthetic pigment $\mathrm{Chl}$ a and $\mathrm{Chl} \mathrm{c}$ by $15.7 \%$ and $8.5 \%$, whereas carotenoid content increased by $45.9 \%$ in supra-optimum PAR which displays potential interest as antioxidant agent in addition to total phenolic content and radical scavenging activity. The results suggest that combined stress of high light and nitrogen deprivation shifts the metabolic physiology from protein synthesis to energy reserve (carbohydrate and lipid) and accumulation of saturated fatty acid on expense of unsaturated fatty acid except docosahexaenoic acid. These valuable compounds exhibit potential applications in mariculture, nutraceutical and biofuel industry.

Keywords: Isochrysis galbana; Photosynthetically active radiation; Nitrate deprivation; Biochemical composition; Pigments, Antioxidant.

\section{INTRODUCTION}

Marine phytoplankton which includes different groups of microalgae, cyanobacteria and diatoms are primary producer of organic matter to ocean interior and to higher trophic levels via food chain. Recently, Microalgae seeks the interest for biotechnological purposes due to their valuable biomass components and ability to accumulate and store secondary metabolites that have diverse application in aquaculture, nutraceutical, pharmaceutical and biofuel industry[1,2,3]. Interesting biomass compounds that could be produced by microalgae includes carotenoids, fatty acids, amino acid, proteins, polysaccharides, vitamins, and phenolic compounds, which exhibits potential application in food and pharmaceutical industries. Isochrysis galbana is a golden brown flagellated microalgae belonging to haptophyta species. This genus have been used for centuries in aquaculture as animal feed due to its comparatively high growth rate, small size, non-toxic and superior nutritional value [4]. Various environmental factors as temperature, $\mathrm{pH}$, salinity, nitrogen availability, and light exert an impact on growth and biochemical composition of microalgae cells. Since variation in irradiance is a typical event in cultivation system under natural conditions, indoor or outdoor photobioreactors etc. Its influence on the biochemical composition of microalgae has considerable physiological and biotechnological importance. Light is one of the key factors that determines the amount of available energy for the photosynthetic process and thereby affects growth. Previous study reported that nitrate is a significant nutrient in the media that can provoke important changes in the growth and biochemical composition of microalgal species $[5,6,7]$. There are meager reports on combined impact of high light intensity and nitrate deprivation induced oxidative stress on biomass production and biomass composition of I. galbana. Therefore, the objective of this paper is to point out how change in light intensity along with nitrate concentration in batch culture affects the growth and biochemical composition of microalgae. Beside, aqua culturist, demand for nutraceutical substance and biofuel on the world market, raised the needs of improved knowledge of its growth characteristic and biochemical composition for higher production of particular valuable metabolites with high mass productivity. Therefore, it is important to investigate the interactive effect of light and nitrate limitation on growth and biochemical composition of microalgae.

\section{MATERIALS AND METHODS}

\section{Algal sample and growth condition}

The starter culture of marine microalgae Isochrysis galbana was obtained from Center of Marine and Fishery Research Institute (CMFRI) kochi, India. The experiment was carried out in 1 litre conical flask containing $200-300 \mathrm{ml}$ of growth media. The 
growth media contained autoclaved filtered natural seawater, supplemented with $f / 2$ culture medium [8]. The $\mathrm{f} / 2$ culture medium was composed of $75 \mathrm{mg} \mathrm{L}^{-1} \mathrm{NaNO}_{3}, 5 \mathrm{mg}$ $\mathrm{L}^{-1} \mathrm{NaH}_{2} \mathrm{PO} 4 \mathrm{H}_{2} \mathrm{O}, 1 \mathrm{ml} \mathrm{L}^{-1}$ trace metal solution $\left(3.15 \mathrm{mg} \mathrm{L}^{-1} \mathrm{FeCl}_{3} 6 \mathrm{H}_{2} \mathrm{O}, 4.36 \mathrm{mgL}^{-1}\right.$ $\mathrm{Na}_{2}$ EDTA, $0.0098 \mathrm{mgL}^{-1} \mathrm{CuSO}_{4} 5 \mathrm{H}_{2} \mathrm{O}, 0.0063 \mathrm{mgL}^{-1} \quad \mathrm{Na}_{2} \mathrm{MoO}_{4} 2 \mathrm{H}_{2} \mathrm{O}, 0.022 \mathrm{mgL}^{-1}$ $\left.\mathrm{ZnSO}_{4} 7 \mathrm{H}_{2} \mathrm{O}, 0.01 \mathrm{mg} \mathrm{L}^{-1} \mathrm{CoCl}_{2} 6 \mathrm{H}_{2} \mathrm{O}, 0.18 \mathrm{mgL}^{-1} \mathrm{MnCl}_{2} 4 \mathrm{H}_{2} \mathrm{O}\right)$ and $0.5 \mathrm{ml} / \mathrm{L}$ of vitamin solution ( $0.001 \mathrm{mg} \mathrm{L}^{-1}$ vitamin $\mathrm{B} 12,0.2 \mathrm{mgL}^{-1}$ vitamin $\mathrm{B} 1,0.001 \mathrm{mg}^{-1}$ biotin $^{-1}$ ) were added. In the laboratory, the culture of Isochrysis galbana were grown in a batch culture at temperature of $22-25^{\circ} \mathrm{C}, \mathrm{pH} 8-8.2$ and illumination of $125 \mu \mathrm{mol}$ photon $\mathrm{m}^{-2} \mathrm{~s}^{-1}$ provided by white fluorescent tube for 18:6 h light-dark period. The cultures were shaken manually 2-3 times daily.

\section{Experimental design}

The early log phase culture of $I$. galbana were cultivated under three levels of photosynthetic active radiation (PAR) - Sub-optimum (50 $\pm 1.5 \mu \mathrm{mol}$ photons $\left.\mathrm{m}^{-2} \mathrm{~s}^{-1}\right)$; Optimum $\left(125 \pm 2.5 \mu \mathrm{mol}\right.$ photons $\left.\mathrm{m}^{-2} \mathrm{~s}^{-1}\right)$; and Supra-optimum $(325 \pm 3.5 \mu \mathrm{mol}$ photons $\left.\mathrm{m}^{-2} \mathrm{~s}^{-1}\right)$. Then within each light regime, nitrate content was reduced from $8 \mathrm{mM}$ to $2 \mathrm{mM}$ and $0.5 \mathrm{mM}$ in respective culture medium. A factorial $3 \times 3$ (light intensities $X$ nitrate concentration) experimental design with 3 replicates per treatment was performed. Treatments consisted of three levels of light intensity: $50 \mu \mathrm{mol}$ photon $\mathrm{m}^{-2} \mathrm{~s}^{-}$ 1 (sub-optimum), $125 \mu \mathrm{mol}$ photon $\mathrm{m}^{-2} \mathrm{~s}^{-1}$ (optimum), and $325 \mu \mathrm{mol}$ photon $\mathrm{m}^{-2} \mathrm{~s}^{-1}$ (supra optimum), and three level of nitrate concentration $(8 \mathrm{mM}, 2 \mathrm{mM}$ and $0.5 \mathrm{mM})$.

\section{Measurement of algal growth}

The growth of Isochrysis galbana cells were estimated in terms of optical density (O.D.) and dry weight. Optical density was measured daily at $710 \mathrm{~nm}$ by UV visible spectrophotometer. For dry weight measurement, $50 \mathrm{ml}$ of culture samples were centrifuged at $8000 \mathrm{rpm}$ for 10 minutes. After rinsing twice with ammonium formate, the pellets were dried $6 \mathrm{hr}$ in an oven at $1100 \mathrm{C}$ and then cooled down in desiccators before weighing. All the experiments were carried out in triplicates.

\section{Biochemical analysis and pigment content}

The crude protein was determined by modified Lowery method [9]. The absorbance of the samples was taken at $650 \mathrm{~nm}$ and the concentration was determined using standard curve. Total Protein Content $=$ Wt. of protein (from curve) X 100/ dry cell mass (mg). The content of carbohydrate was estimated by phenol-sulfuric acid method with slight modification[10]. The optical density of the sample was determined against the blank at $490 \mathrm{~nm}$ in a UV-visible spectrophotometer. Carbohydrate Content $(\%)=$ Wt. of carbohydrate (from glucose standard curve) X 100/ dry cell mass (g) and total lipid content of samples were analyzed gravimetrically after extraction with chloroformmethanol (2:1) modified by Bligh and Dyer11. Extracted lipid were converted to methyl esters with methanolic HCL and 2,2-dimethoxy propane via transesterification. Then fatty acid methyl esters were determined by using gas chromatograph (GC) of series SP-2560 $(100 \times 0.25 \mathrm{~mm} ; 0.20 \mu \mathrm{m})$, followed by flame-ionization detection (HewlettPackard, USA). Pigments ( $\mathrm{Chl} \mathrm{a,} \mathrm{Chl} \mathrm{c} \mathrm{and} \mathrm{carotenoids)} \mathrm{were} \mathrm{extracted} \mathrm{in} \mathrm{methanol}$ $(90 \%)$ at $4^{\circ} \mathrm{C}$ overnight and measured by spectrophotometric methods [12].

\section{Antioxidant activity}

Antioxidant activity of the various treatment of Isochrysis cells were determined by quantifying total phenolics content (TPC) present with methanol and calculating the antioxidant activity of the extract by measuring the DPPH free radical scavenging activity. Total phenolics content (TPC) of crude extract was determined by the Folinphenol method following the method of Waterhouse13. $0.1 \mathrm{~mL}$ of methanolic extract was mixed with $1.5 \mathrm{~mL}$ distilled water and then $0.1 \mathrm{~mL}$ of folin cioalteu phenol reagent 
was added. After 3 minutes $1 \mathrm{~mL}$ of sodium carbonate (10\%) was added and $10 \mathrm{ml}$ volume was makeup with distilled water. After incubation of 90 min absorbance was read at $765 \mathrm{~nm}$ and compared with the standard curve prepared by gallic acid. The amount of TPCs was expressed as gallic acid equivalent $\mathrm{g}^{-1}$ dry weight. The DPPH radical scavenging effect of the extracts was determined by the method of Sanja et al with slight modification [14].100 $\mu$ l of extract was mixed with $150 \mu \mathrm{l}$ of DPPH solution and diluted up to $3 \mathrm{ml}$ with pure methanol. Incubate for 15 mins at room temperature in dark and the absorbance of solution was taken at $517 \mathrm{~nm}$ on UV spectrophotometer using methanol as blank. The radical scavenging activity (\%) was expressed as the percentage discoloration of DPPH solution by using the following equation:

Radical scavenging activity $(\%)=($ Acontrol - Asample $) /$ Acontrol X 100

\section{Statistical analysis}

All experiments were done in triplicates and data represent the means \pm SD. The means were analyzed by two- way ANOVA and significant differences between treatments were tested using Duncan's multiple range test (DMRT). $P$-values $<0.05$ were considered significant. Statistical analyses were carried out using Statistical Package for the Social Sciences (SPSS) 10.0.

\section{RESULTS}

\section{Growth pattern and dry weight}

To evaluate the effect of light and nitrate concentration on growth, absorbance at $710 \mathrm{~nm}$ were measured. The growth curve of $l$. galbana cells treated with different concentration of nitrate $(8 \mathrm{mM}, 2 \mathrm{mM}, 0.5 \mathrm{mM})$ illustrated in figure 1 . Result reveals that nitrogen depletion negatively affects the growth of cells at all light regime. It was also observed that stress of high light intensity for short period stimulates the growth of $l$. galbana more efficiently than low light intensity. The maximum growth was observed at $325 \mu \mathrm{mol} \mathrm{m} \mathrm{m}^{-2} \mathrm{~s}^{-1}$ PAR. Growth measured in term of dry weight was shown in figure 2. The biomass content significantly decreased with deprivation of light and nitrate concentration from 0.97 to $0.43 \mathrm{~g} \mathrm{~L}^{-1}$. The culture grown under supra-optimum PAR with sufficient nitrate concentration attained a highest dry weight $\left(0.97 \pm 0.028 \mathrm{~g} \mathrm{~L}^{-1}\right)$ followed by culture grown in optimum PAR $\left(0.83 \mathrm{M} \pm 0.042 \mathrm{~g} \mathrm{~L}^{-1}\right)$. After deprivation of nitrate content in growth medium, growth was declined considerably in dose dependent order. Result reveals that with deprivation of nitrate $(2 \mathrm{mM}, 0.5 \mathrm{mM})$ growth lowers by $60.1 \%$ and $61.9 \%$ in sub-optimum PAR and $26.5 \%$ and $34.9 \%$ in supra-optimum respectively, over the values recorded in their respective controls.
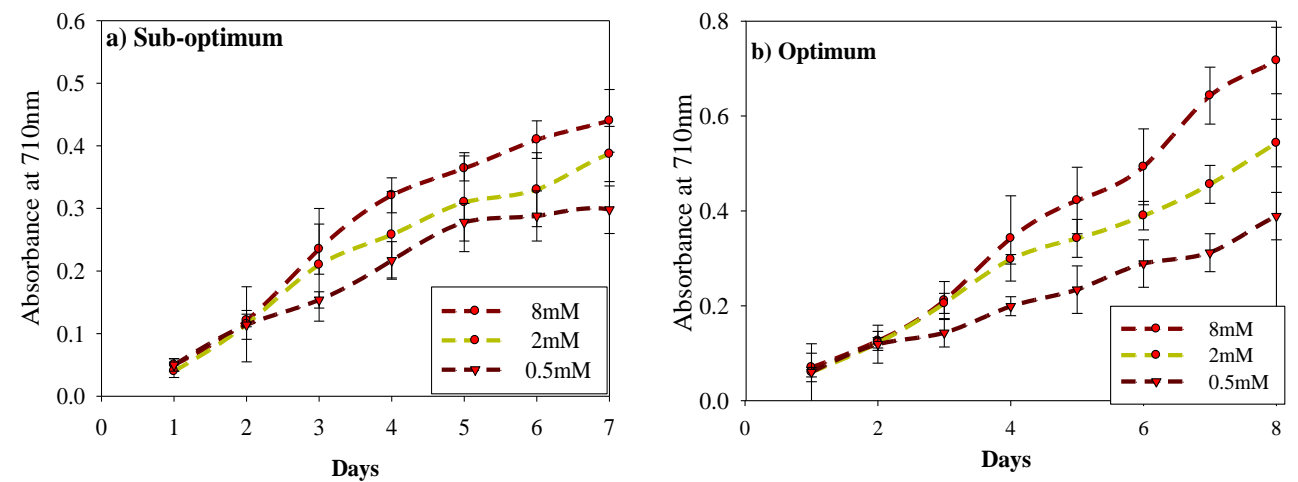


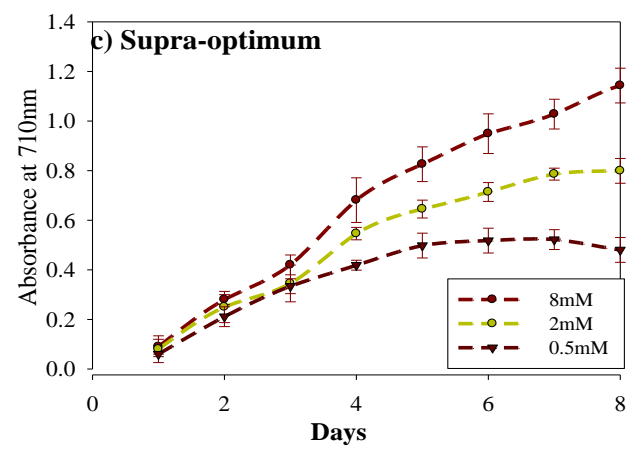

Figure 1: Growth curve at three different nitrate concentrations under a) Sub optimum b) Optimum level $1 \mathrm{c}$ ) Supra-Optimum of PAR.

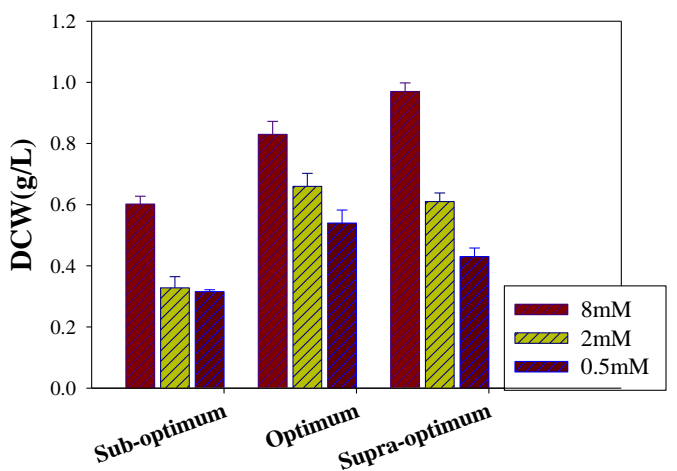

Figure 2. Impact of nitrate deprivation on dry weight of Isochrysis galbana cultivated under three levels (sub-optimum, optimum and supra-optimum level) of PAR. Data are the means \pm standard error of three replicates in each experiment.

\section{Biochemical composition and pigment contents}

In figure 3, the variations of the determined biochemical compositions during the cultivation of $I$. galbana under different light intensity and nitrate concentration were illustrated. It had reported that in each light regime, all biochemical parameters were significantly different $(p \leq 0.05)$ at all three levels of nitrate deprivation, although post hoc test (Duncan's test) reveals some culture were insignificant in different light regime. The result of present study revealed slight increase in protein content with increase in light intensity in nitrate untreated cells whereas deprivation of nitrate content $(2 \mathrm{mM}, 0.5 \mathrm{mM})$ decreased protein content by $13.7 \%$ and $33.9 \%$ respectively, in suboptimum PAR and $36.9 \%$ and $51.9 \%$ respectively, in supra-optimum PAR. In nitrate untreated cells, carbohydrate and lipid accumulates by $22.3 \%$ and $14.4 \%$ respectively, in supra-optimum PAR. Further, with deprivation of nitrate content in media carbohydrate and lipid accumulates with increasing order of doses (figure 3 ). The pigment contents of I galbana significantly $(p \leq 0.05)$ affected by deprivation of nutrient and light intensity in most of cultures (figure 4). Our result found that with untreated nitrate cells maximum content of photosynthetic pigment $\mathrm{Chl} a$ and $\mathrm{Chl} c(4.67 \pm 0.28$ $\mathrm{mg} \mathrm{L}-1$ and $3.82 \mathrm{mg} \mathrm{L}^{-1}$ ) attained under supra-optimum PAR while maximum carotenoid content $\left(4.89 \pm 0.256 \mathrm{mg} \mathrm{L}^{-1}\right)$ reported in cell grown under sub-optimum PAR. Similar trend is found in other studies Dunaliella salina, Chlorella zofingiensis , Isochrysis galbana $[14,15]$. 

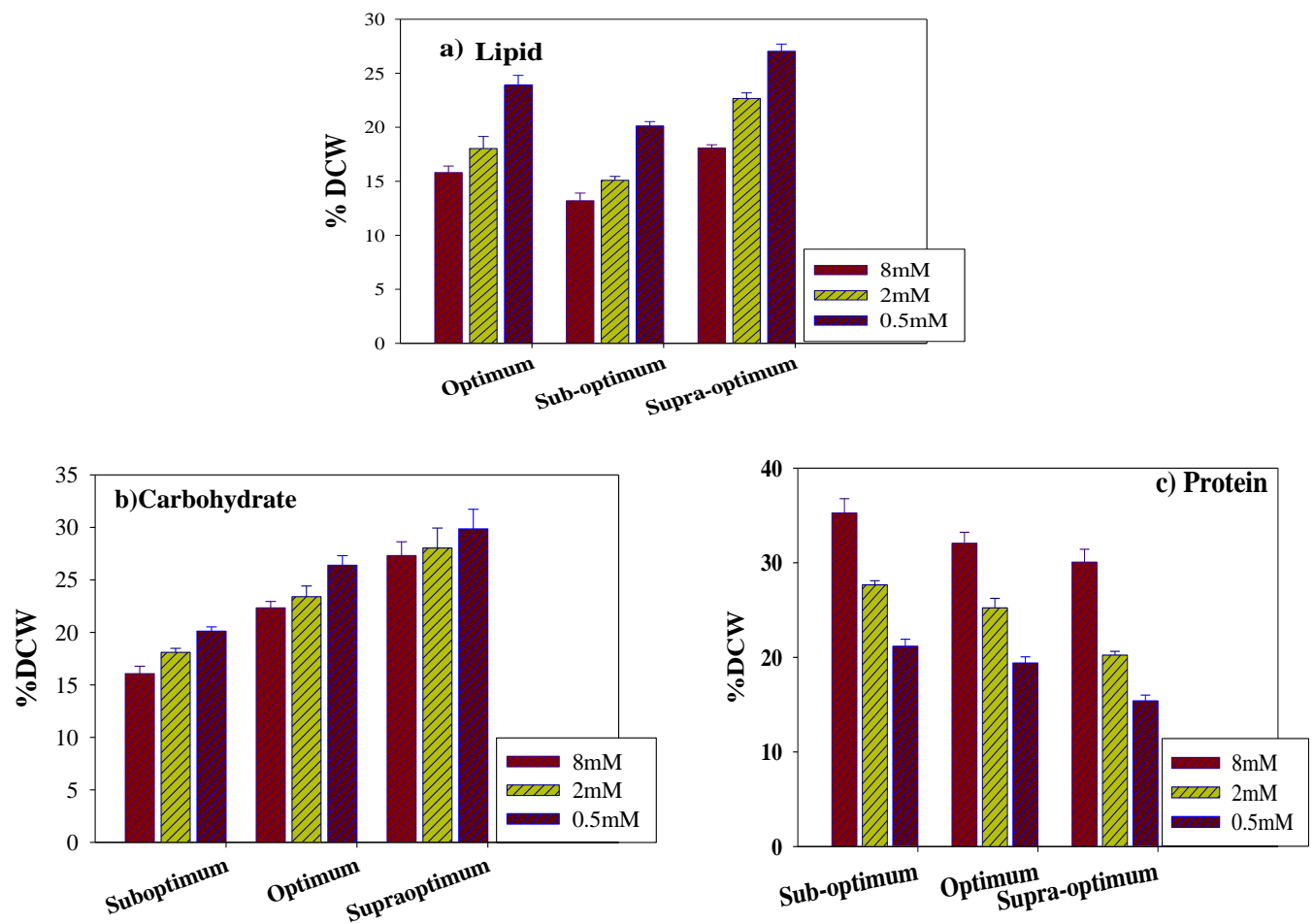

Figure 3. Effect of nitrate deprivation on a) Lipid b) Carbohydrate c) Protein content of Isochrysis galbana cell grown under sub-optimum,optimum and supra-optimum level of PAR. Data are the means \pm standard error of three replicates in each experiment.
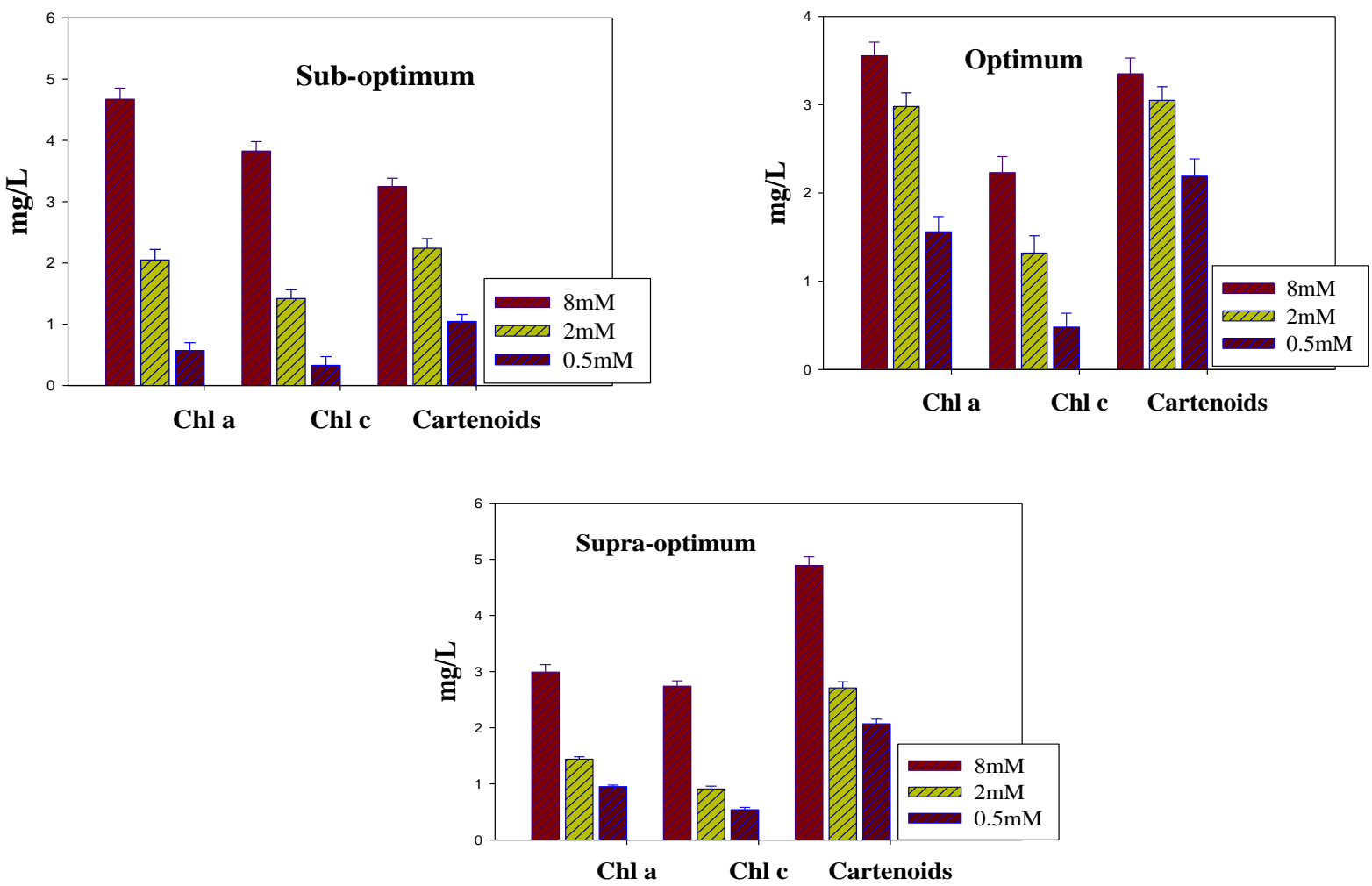

Figure 4: Effect of nitrate deprivation on pigments under a) Sub-optimum b) Optimum light, c) Supra-optimum PAR. Data are the means \pm standard error of three replicates in each experiment. 


\section{Fatty acid Profile}

The previous studies on fatty composition of Isochrysis galbana were revealed that it contains Myristic acid (C16:0), Palmitic acid (C18:0), Oleic acid (C18:1, n-9) and DHA $(\mathrm{C} 22: 6, \mathrm{n}-3)$ as major fatty acid. In this study, we investigated the effect of varying light intensity and nitrate deprivation on five major fatty acid compositions (FAME) which are presented in table 1. In parallel to previous studies, we observed that high light conditions or severe nitrogen limitations were associated with significant increase of palmitic, C16:0 (10.38-14.3 $\mathrm{mg} \mathrm{g}^{-1}$ ) and oleic, C18:1 (15.89-21.78 $\mathrm{mg} \mathrm{g}^{-1}$ ) acids and decrease in the percentage of the polyunsaturated fatty acid, predominately Stearidonic acid, C18:4(18.54-11.47). Although, the highly unsaturated fatty acid docosahexaenoic acid, C22:6 slightly increased from $12.38 \mathrm{mg} \mathrm{g}^{-1}$ to $15.48 \mathrm{mg} \mathrm{g}^{-1}$ under high PAR and low nitrogen concentration.

Table 1: Effect of nitrogen depletion on fatty acid profile (\% of total) of Isochrysis galbana cultivated in three different light regimes. All fatty acids are expressed as $\mathrm{mg}^{\mathrm{g}}$ 1 .

\begin{tabular}{cccccccccccc}
\hline Fatty acids & Common name & \multicolumn{3}{c}{ Sub-optimum } & \multicolumn{3}{c}{ Optimum } & \multicolumn{4}{c}{ Supra-optimum } \\
\cline { 3 - 10 } & & $8 \mathrm{mM}$ & $2 \mathrm{mM}$ & $0.5 \mathrm{mM}$ & $8 \mathrm{mM}$ & $2 \mathrm{mM}$ & $0.5 \mathrm{mM}$ & $8 \mathrm{mM}$ & $2 \mathrm{mM}$ & $0.5 \mathrm{mM}$ \\
\hline $\mathbf{C 1 4 : 0}$ & Myristic acid & 16.96 & 16.93 & 17.09 & 17.06 & 17.1 & 17.21 & 17.11 & 17.2 & 17.34 \\
$\mathbf{C 1 6 : 0}$ & Palmitic acid & 10.38 & 11.46 & 12.1 & 11 & 11.7 & 12.3 & 12.08 & 13.1 & 14.3 \\
$\mathbf{C 1 8 : 1 , n - 9}$ & Oleic acid & 15.89 & 16.5 & 17.08 & 16.4 & 17.23 & 18.32 & 19.1 & 20.45 & 21.78 \\
$\mathbf{C 1 8 : 2 , \mathbf { n } - 6}$ & Linoleic acid & 6.29 & 5.99 & 5.2 & 5.05 & 3.78 & 3.55 & 2.94 & 2.58 & 2.1 \\
$\mathbf{C 1 8 : 3 , n - 3}$ & $\alpha$-Linolenic acid & 2.27 & 2.15 & 1.27 & 2.51 & 1.89 & 1.51 & 3.54 & 2.32 & 1.54 \\
$\mathbf{C 1 8 : 4 , \mathbf { n } - 3}$ & Stearidonic acid & 18.54 & 15.7 & 13.7 & 16.2 & 15.8 & 14.3 & 14.9 & 12.3 & 11.47 \\
$\mathbf{C 2 0 : 5 , \mathbf { n } - 3}$ & $\begin{array}{c}\text { Eicosa pentaenoic } \\
\text { acid (EPA) }\end{array}$ & 0.98 & 0.82 & 0.7 & 0.92 & 0.8 & 0.76 & 0.87 & 0.67 & 0.55 \\
$\mathbf{C 2 2 : 6 , n - 3}$ & $\begin{array}{c}\text { Docosahexaenoic } \\
\text { acid (DHA) }\end{array}$ & 12.38 & 12.66 & 13.07 & 13.3 & 13.91 & 14.28 & 15.01 & 15.25 & 15.48 \\
& & & & & & & & & \\
\hline
\end{tabular}

\section{Antioxidant activity}

Total phenolic compounds and free radical scavenging activities of methanol extract of different treatments were studied at $250 \mu \mathrm{l} / \mathrm{ml}$ concentrations. The result of present studies found that highest quantity of TPC (3.77mg GAE DW $\left.{ }^{-1}\right)$ and antioxidant activity $(72.3 \%)$ were observed in culture grown in supra-optimum PAR with $8 \mathrm{mM}$ of sodium nitrate. Figure 5 illustrated that deprivation of nitrate concentration decreases both TPC and free radical scavenging activity and lowest quantity of TPC $(1.85 \mathrm{mg}$ GAE DW ${ }^{-1}$ ) and DPPH activity (37.5\%) were observed in culture grown in sub-optimum PAR with $0.5 \mathrm{mM}$ of sodium nitrate. 

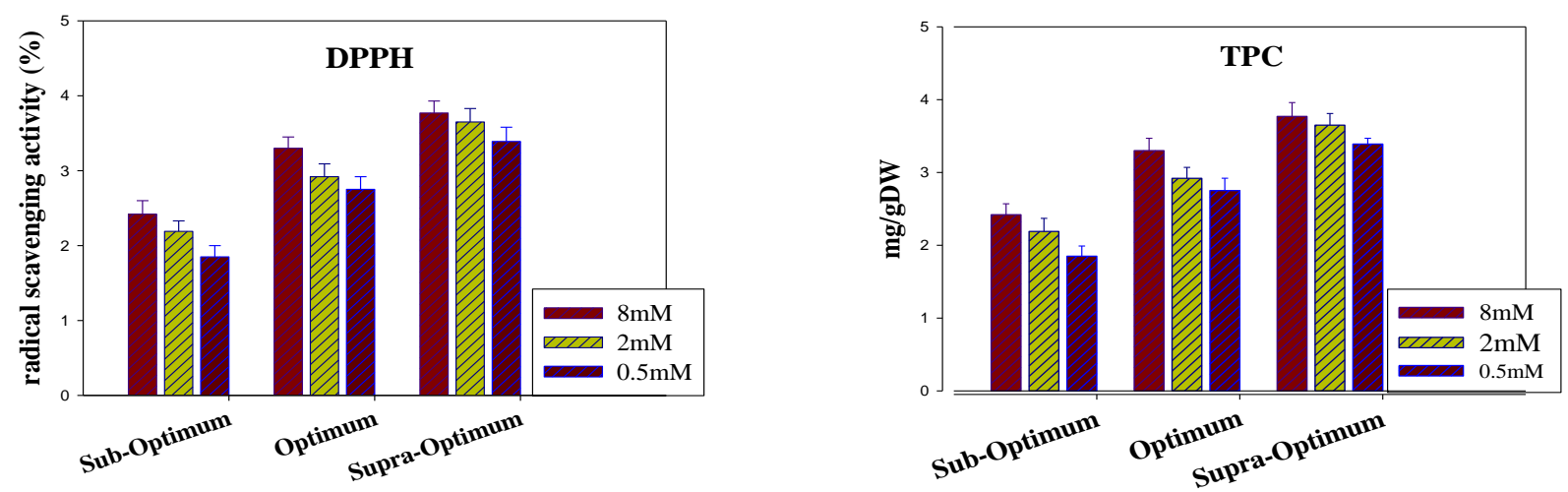

Figure 5: Impact of nitrate deprivation on TPC and DPPH free radical scavenging activity of Isochrysis galbana cultivated under three levels (sub-optimum,optimum and supra-optimum level) of PAR. Data are the means \pm standard error of three replicates in each experiment.

\section{DISCUSSIONS}

\section{Growth pattern and dry weight}

I. galbana is a photoautotrophic microalgae its growth is highly influence by irradiance supply. In present study, wide growth permissive range of light intensity for this alga has been identified. It had found that stress of high light for short period stimulates the growth of Isochrysis galbana cell more efficiently than low light intensity. This could be because under stress (such as high light intensity) microalgae might increase their size in order to survive in stressful environments. Other study advocated this result and reasoned that a under supra-optimum PAR microalgae would turn out increased amounts of light energy into usable chemical energy which would result in an increase in algal biomass. At sub-optimum PAR, minimum growth has been observed and further growth decreased linearly with nitrate deprivation. In support of this, one of previous study stated that the growth of phytoplankton in large-scale batch cultures usually slowed by light limitation or terminated by nutrient limitation (N, P, Si) especially in old culture because excess of cells produces self shading in culture [15]. A maximum growth was found in cell grown at $325 \mu \mathrm{mol} \mathrm{m}^{-2} \mathrm{~s}^{-1}$ this suggesting that this species is able to grow under a wide range of light conditions with suffering an extensive stress that makes necessary cell adaptation. Since nitrogen is a major component in many biological macromolecules like protein, chlorophyll, photosystem, enzymatic and genetic materials $[16,17]$. Nitrogen deprivation is also a major limiting factor affecting the growth and biomass production $[18,19]$. Previous study observed that nitrogen limitation decreases the synthesis of photosynthetic pigments thereby also hampers the processes of photosynthesis and assimilation in turn positively affects the cell density or microalgal biomass $[17,20,21]$. The present study observed that nitrate deprivation has more pronounced effect on growth pattern and dry weight of microalgae than light deprivation [22]. Isochrysis galbana attained maximum cellular density at $8 \mathrm{mM} \mathrm{NaNO}$ and biomass content significantly decreased with a decrease in nitrate. This indicates that nitrogen starvation slows down the metabolic activity and cell division in I. galbana. Similar results have also been observed in previous studies $[23,24]$. The lowest dry weight have been found in cell grown in low light with $\mathrm{N}$ deficient condition (sub-optimum- $0.5 \mathrm{mM}$ ) resulted in only $0.43 \mathrm{gL}^{-1}$ (dry cell weight). The lower biomass yield in the $\mathrm{N}$-limited treatment was primarily caused by lower specific growth rate and may be due to a combination of lower cell abundance and smaller cells in the N-limited treatment. This result is supported by observation of other studies in which nitrate and salinity influence the growth in Tetraselmis sp. and reported that limitation of nitrogen may limit the cell growth25. Previous research demonstrated that low levels of nitrogen in media reduced the productivity of 
microalgae as they may have an adverse effect on the metabolism, cell division and thereby reducing cell population levels [26].

\section{Biochemical compositions and pigments}

Stress of high light and nitrate deprivation affects the metabolic activity of cell and divert the cell from protein synthesis to carbohydrate and lipid accumulation. Under supra-optimized PAR, synthesis of carbohydrate and lipid increased by $22.3 \%$ and $14.4 \%$ respectively. This is because under high light intensity cell fix more carbon dioxide to storage products lipids and carbohydrates because they are hydrophobic in nature and have highly reduced states. In addition they efficiently packed in small compartment of cells and can also be used during adverse conditions for cell survival and proliferation [27]. Figure 3 illustrated the proximate composition of Isochrysis galbana under different levels of stress and observed a similar trend widely documented in the previous literatures $[28,29,30]$. Result of study observed that nitrate deprivation facilities the accumulation of carbohydrate and lipid under both suboptimum and supra-optimum PAR. Nitrogen limitation interrupts the Kreb's cycle thus contributing to fatty acid formation [31]. This increased lipid concentration was coupled to decrease in both dry weight and total protein content. It has been observed that cultivation under nitrogen deficient conditions for short time leads to a sharp increase in the lipid or carbohydrate content because nitrogen starvation limited the rate of cell division and shifts anabolic pathways from protein synthesis to produce reserve substance like carbohydrate or lipid. This behavior is consistent with numerous studies demonstrated that under $\mathrm{N}$-limited conditions, lipid and carbohydrate contents were improved in many algal species like Neochloris oleoabundan [32] HK-129, Thermosynechococcus sp, Chlorella vulgaris [33], Scenedesmus obliquus CNW-N [34], Nannochloropsis sp., and Tetraselmis suecica [35] .Under supra-optimum PAR, I. galbana similarly to other photosynthetic organisms showed an acclimation response by decreasing the $\mathrm{Chl}$ a content and accumulating carotenoids. Previous studies observed that under high light intensities to reduce the light harvesting ability chlorophyll a content decreases and carotenoids accumulates to prevent the absorption of surplus light energy by the photosynthetic machinery and thereby protect the photosynthetic apparatus from oxidative stress [36,37].

Since, chlorophyll is a nitrogenous compound; its content and composition are greatly influenced by nitrate concentration in the growth medium. Figure 4 illustrated that with limitation of nitrate content, photosynthetic pigments and carotenoids decreased significantly $(p<0.05)$ whereas ratio of $\mathrm{Chl} a / \mathrm{Chl} c$ and car/total $\mathrm{Chl}$ increased in all three light regime. Nitrogen is a key element for the synthesis of protein and its limitation lowers protein synthesis rate. Since proteins involves in photosystem reaction center and photosynthesis electron transport system therefore nitrogen limitation impairs the rate of photosynthesis too. These are similar to previous studies [38]. In our study, under same light regime the limitation of nitrogen significantly decreased all photosynthetic pigments viz. Chl $a$, Chl $c$ and total carotenoids. As shown in figure 4, reduction in nitrate in cultivation medium from $8 \mathrm{mM}$ to $0.5 \mathrm{mM}$ has reduced the total chlorophyll and carotenoids by about $83.8 \%$ to $89.4 \% \mathrm{DW}$ and $78.1 \%$ to $67.7 \%$ DW respectively under different light regime. However, the ratio of $\mathrm{Chl} \mathrm{a} / \mathrm{c}$ and caro/total Chl was found to increase in nitrogen limited cultures, thus indicating the decrease in light harvesting complex and PS II activity. This is further supported by previous studies [39].

\section{Fatty acid profile}

The results of present study were found in consistent to the earlier finding $[40,41,42]$ and suggested that fatty acid composition within cells changes with changing the growth condition such as light intensity or nitrate concentration. We observed that there is shift of one group of FAs, includes myristic acid, LA, ALA 
and SDA, to a second group of FAs including palmitic acid and oleic acid, with nitrogen limitation and high light intensity. Under high light intensity, an excess of energy is used by the cells for producing storage lipids, mostly SFA and MUFA which are commonly involved in the formation of thylakoid membranes and under low PAR elevation in percentages of PUFA predominantly 18:4(n-3), 20:5(n-3) and 18:5(n-3) were observed which was accompanied by an increase in chlorophyll a content. The increase in MUFA (oleic acid) can be explained with the central role of oleic acid in elongation and saturation of fatty acid $[43,44,45]$. The decrease in PUFA would be due to its role in synthesis of structural components and to increase light absorption and light utilization efficiency [46], [47] explained the changes in fatty acid composition of cells under different light regimes and explained the relation of functioning of photo systems and processes of production and desaturation of fatty acids. DHA is the prominent omega 3 fatty acid in Isochrysis galbana which increases under high light intensity and severe nitrogen depletion. There are multiple theories for contradictory increasing trend of DHA which includes it's imperative role in membrane physiology of $I$ galbana [42], association of DHA with anti-photooxidation procedure [48] and some studies suggested that the light promotes its synthesis by activation of desaturase enzymes [49].

\section{Antioxidant activity}

Result showed that altering the culture conditions (light intensity and nitrate deprivation) has significant effect on antioxidant potential of microalgae. Cells grown under high PAR showed highest amount of TPC and antioxidant activity this highlights the key role of light on pigment photoprotection mechanism. Figure 5 elicited that the deprivation of nitrate in media decline the TPC and antioxidant activity of Isochrysis galbana cells. Similar results were observed and explained that nitrogen is required for synthesis of the aromatic amino acids (AAA), which may be playing an important role as precursors for biosynthesis of phenolic compounds [50,51] .

\section{CONCLUSION}

Our study observed that combined manipulation of the nutrient deficiency and high light intensity is important to achieve algal cells with high lipid and carbohydrate productivity. The present experiment found that high light (325 $\mu \mathrm{mol}$ photons m-2 s-1) facilitates rapid growth and accumulation of reserve like carbohydrate and lipid content. The combination of high light and nitrogen-deficiency stresses are of particular interest for establishing the photobiotechnology of this alga, as lipid especially docosahexaenoic acid (DHA) is a valuable nutraceutical component of Isocrysis galbana. It is possible to manipulate the biochemical composition of Isochrysis galbaba by changing the light regime and nutrient content which could be used for aquaculture, human nutrition, pharmaceutical, biofuel and other industrial application. The stress of high light intensity increases the total carotenoids content and the antioxidant activity which displays some potential interest as antioxidant agent. Stress of high light intensity and nutrient deficiency could also be used to induce carbohydrate and lipid accumulation, which could be used in mariculture feeds, nutraceutical and biofuel industry.

Acknowledgments: I highly acknowledge UGC for their financial support under the post doctoral fellowship scheme, vide letter no. - PDFWM-2015-17-UTT-37527 and Center for Food \& Technology, University of Allahabad.

Conflicts of Interest: The authors declare that there is no conflict of interest regarding the publication of this paper. 


\section{REFERENCES}

1. Pal D, Khozin-Goldberg I, Cohen Z, Boussiba S. The effect of light, salinity, and nitrogen availability on lipid production by Nannochloropsis $s p$. Applied Microbioliogy and Biotechnology. 2011;90: 429-41.

2. Yao C, Ai J, Cao X, Xue S, Zhang W. Enhancing starch production of a marine green microalga Tetraselmis subcordiformis through nutrient limitation. Bioresource Review Technology. 2012; 118:438-44.

3. Chtourou H, Dahmen I, Hassairi I, Abdelkafi S, Sayadi S, Dhouib A. Dunaliella sp.: a Wild Algal Strain Isolated from the Six-Tunisia Solar Evaporating Salt-Ponds, a High Potential for Biofuel Productio Purposes. Journal of Biobased Materials and Bioenergy. 2014; 8:1-8.

4. Alkhamis Y, Qin JG. Cultivation of Isochrysis galbana in phototrophic, heterotrophic, and mixotrophic conditions. BioMed Research International. 2013

5. Xu N, Zhang X, Fan X, Han L, Zeng C. Effects of nitrogen source and concentration on growth rate and fatty acid composition of Ellipsoidion sp. (Eustigmatophyta). Journal of Applied Phycology. 2001;13(6):463-9.

6. El-Kassas HY. Growth and fatty acid profile of the marine microalga Picochlorum sp. grown under nutrient stress conditions. The Egyptian Journal of Aquatic Research. 2013;39(4):233-9.

7. Safdar W, Shamoon M, Zan X, Haider J, Sharif HR, Shoaib M, Song Y. Growth kinetics, fatty acid composition and metabolic activity changes of Crypthecodinium cohnii under different nitrogen source and concentration. AMB Express. 2017;7(1):85.

8. Guillard RRL. Culture of phytoplankton for feeding marine invertebrates. In: Smith WL, Chanie M. H, editor. New York:Plenum Press;1975, p 29-60.

9. Lowry $\mathrm{OH}$, Rosebrough NJ, Farr AL, Randall RJ. Protein measurement with the Folin phenol reagent. Journal of Biological Chemistry. 1951; 193:265-75.

10. DuBois M, Gilles KA, Hamilton JK, Rebers PT, Smith F. Colorimetric method for determination of sugars and related substances. Analytical chemistry. 1956;28(3):350-6.

11. Bligh EG, Dyer WJ. A rapid method of total lipid extraction and purification. Canadian Journal of Biochemistry and Physiology. 1959; 37:911- 7.

12. Mitchell BG, Kiefer DA. Determination of absorption and fluorescence excitation spectra for phytoplankton. Lecture Notes on Coastal and Estuarine Studies. 1984; 8:157-169.

13. Waterhouse AL. Determination of total phenolics. Current Protocols in Food Analytical Chemistry. $2001 ;$ I1.1-I1.1.8

14. Sanja SD, Sheth NR, Patel NK, Dhaval P, Biraju P. Characterization and evaluation of antioxidant activity of portulacaoleracea. International Journal of Pharmaceutical Sciences. 2009; 1:74-84.

15. Johnsen G, Sakshaug E. Biooptical characteristics of PSII and PSI in 33 species (13 pigment groups) of marine phytoplankton, and the relevance for pulse-amplitude-modulated and fast-repetition-rate fluorometry. Journal of Phycology. 2007;43(6):1236-51.

16. Cai T, Park SY, Li Y. Nutrient recovery from wastewater streams by microalgae: status and prospects. Renewable Sustainable Energy Review. 2013; 19:360-9.

17. Hu Q. Environmental effects on cell composition. In: Richmond A, Hu Q, editors. Handbook of Microalgal Culture. Applied Phycology and Biotechnology. 2nd ed. Wiley Blackwell, West Sussex. 2013, p 114-122.

18. Li Y, Horsman M, Wang B, Wu N, Lan CQ. Effect of nitrogen source on cell growth and lipid accumulation of green alga Neochloris oleoabundans. Applied Microbiology and Biotechnology. 2008; 81:629-36.

19. Simionato D, Block MA, La Rocca N, Jouhet J, Maréchal E, Finazzi G, Morosinotto T. The response of Nannochloropsis gaditana to nitrogen starvation includes de novo biosynthesis of triacylglycerols, a decrease of chloroplast galactolipids, and reorganization of the photosynthetic apparatus. Eukaryotic Cell. 2013; 12:665-76. 
20. Saha SK, Uma L, Subramanian G. Nitrogen stress induced changes in the marine cyanobacterium Oscillatoriawillei BDU 130511. FEMS Microbial. Ecology. 2006; 45:26372.

21. Serpa R, Calderón A. Efecto de diferentes fuentes de nitrógeno en el contenido de carotenoides y clorofila de cuatro cepas peruanas de Dunaliella salina TEOD. Journal of Applied Ecology. 2006;5(12):93-9.

22. Guedes AC, Amaro HM, Malcata FX. Microalgae as sources of high added-value compounds:a brief review of recent work. Biotechnology Progress. 2011; 27:597-613.

23. Dayananda C, Sarada R, Usha Rani M, Shamala TR, Ravishankar GA. Autotrophic cultivation of Botryococcus braunii for the production of hydrocarbons and exopolysaccharides in various media. Biomass Bioenergy. 2007; 31:87-93

24. Mandal S, Mallick N. Microalga Scenedesmus obliquus as a potential source for biodiesel production. Applied Microbiology and Biotechnology. 2009;84(2):281-91.

25. da Coêlho AAC, Barros MUG, Bezerra JHC, da Silva JWA, Moreira RL, Farias WRL. Growth of the microalgae Tetraselmis tetrathele and nitrate deprivation in culture medium Guillard f/2 and Conway. Acta Scientiarum. Biololical Science. 2013; 35:163-8.

26. Nigam S, Rai MP, Sharma R. Effect of nitrogen on growth and lipid content of Chlorella pyrenoidosa. American Journal of Biochemistry and Biotechnology. 2011; 7:124-9.

27. Courchesne NMD, Parisien A, Wang B, Lan CQ. Enhancement of lipid production using biochemical, genetic and transcription factor engineering approaches. Journal of Biotechnology. 2009;141(1-2):31-41.

28. Silva AF, Lourenço SO, Chaloub RM. Effects of nitrogen starvation on the photosynthetic physiology of a tropical marine microalga Rhodomonas $s p$. (Cryptophyceae). Aquatic Botany. 2009;91(4):291-7.

29. Siaut M, Cuiné S, Cagnon C, Fessler B, Nguyen M, Carrier P, Beyly A. Oil accumulation in the model green alga Chlamydomonas reinhardtii characterization, variability between common laboratory strains and relationship with starch reserves. BMC Biotechnology. $2011 ; 11: 1-15$.

30. Praveen kumar R, Shameera K, Mahalakshmi G, Akbarsha MA, Thajuddin N. Influence of nutrient deprivations on lipid accumulation in a dominant indigenous microalga Chlorella $s p$ : Evaluation for biodiesel production. Biomass Bioenergy. 2012; 37:60-6.

31. Tan KW, Lee YK. The dilemma for lipid productivity in green microalgae: importance of substrate provision in improving oil yield without sacrificing growth. Biotechnology for biofuels. 2016;9(1):255.

32. Sun X, Cao Y, Xu H, Liu Y, Sun J, Qiao D, Cao Y. Effect of nitrogen-starvation, light intensity and iron on triacylglyceride/carbohydrate production and fatty acid profile of Neochloris oleoabundans HK-129 by a two-stage process. Bioresource Technology. 2014; 155:204-12.

33. Ho SH, Huang SW, Chen CY, Hasunuma T, Kondo A, Chang JS. Characterization and optimization of carbohydrate production from an indigenous microalga Chlorella vulgaris FSP-E. Bioresource Technology. 2013; 135:157-65.

34. Chu FF, Chu PN, Shen XF, Lam PK, Zeng RJ. Effect of phosphorus on biodiesel production from Scenedesmus obliquus under nitrogen-deficiency stress. Bioresource Technology. 2014; 152:241-6.

35. Biondi N, Cheloni G, Tatti E, Decorosi F, Rodolfi L, Giovannetti L, Viti C, Tredici MR. The bacterial community associated with Tetraselmis suecica outdoor mass cultures. Journal of Applied Phycology. 2017;29(1):67-78.

36. Sánchez Saavedra MP, Voltolina D. Effect of photon fluence rates of white and blue-green light on growth efficiency and pigment content of three diatom species in batch cultures. Ciencias Marinas. 2002;28(3).

37. Ak I. Effects of light intensity, salinity and temperature on growth in CAMALT1 strain of Dunaliella viridis Teodoresco from Turkey. Journal of Biological Sciences. 2008; 8:1356-9. 
38. Deng MD, Moureaux T, Cherel I, Boutin JP, Caboche M. Effects of nitrogen metabolites on the regulation and circadian expression of tobacco nitrate reductase. Plant Physiology and Biochemistry. 1999; 29:239-48.

39. Marin N, Morales F, Lodeiros C, Tamigneaux E. Effect of nitrate concentration on growth and pigment synthesis of Dunaliella salina cultivated under low illumination and preadapted to different salinities. Journal of Applied Phycology. 1998;10(4):405-11.

40. Sukenik A, Wahnon $R$. Biochemical quality of marine unicellular algae with special emphasis on lipid composition. I. Isochrysis galbana. Aquaculture. 1991 Sep 1;97(1):61-72.

41. Hodgson PA, Henderson RJ, Sargent JR, Leftley JW. Patterns of variation in the lipid class and fatty acid composition of Nannochloropsis oculata (Eustigmatophyceae) during batch culture. Journal of Applied Phycology. 1991 Jun 1;3(2):169-81.

42. Tzovenis I, De Pauw N, Sorgeloos P. Optimisation of T-ISO biomass production rich in essential fatty acids: II. Effect of different light regimes on the production of fatty acids. Aquaculture. 2003 Feb 10;216(1-4):223-42.

43. Reitan KI, Rainuzzo JR, Olsen Y. Effect of nutrient limitation on fatty acid and lipid content of marine microalgae 1. Journal of Phycology. 1994 Dec;30(6):972-9.

44. Huerlimann R, Steinig EJ, Loxton H, Zenger KR, Jerry DR, Heimann K. Effects of growth phase and nitrogen starvation on expression of fatty acid desaturases and fatty acid composition of Isochrysis aff. galbana (TISO). Gene. 2014 Jul 15;545(1):36-44.

45. Wang X, Fosse HK, Li K, Chauton M, Vadstein O, Reitan KI. Influence of nitrogen limitation on lipid accumulation and EPA and DHA content in four marine microalgae for possible use in aquafeed. Frontiers in Marine Science. 2019; 6:95.

46. Zhukova NV, Titlyanov EA. Fatty acid variations in symbiotic dinoflagellates from Okinawan corals. Phytochemistry. 2003 Jan 1;62(2):191-5.

47. Klyachko-Gurvich GL, Pronina NA, Tsoglin LN, Semenenko VE, Ladygin VG. Uncoupled functioning of separate photosystems: 1 . Characteristics of fatty acid desaturation and its role. Russian Journal of Plant Physiology. 2000;47(5):603-12.

48. Ohlrogge J, Browse J. Lipid biosynthesis. The Plant Cell. 1995 Jul;7(7):957.

49. Klyachko-Gurvich GL, Tsoglin LN, Doucha J, Kopetskii J, Shebalina IB, Semenenko VE. Desaturation of fatty acids as an adaptive response to shifts in light intensity 1 . Physiologia Plantarum. 1999 Oct;107(2):240-9.

50. Colla LM, Furlong EB, Costa JA. Antioxidant properties of Spirulina (Arthospira) platensis cultivated under different temperatures and nitrogen regimes. Brazilian Archives of Biology and Technology. 2007;50(1):161-7.

51. El-Baky HA, El Baz FK, El-Baroty GS. Production of phenolic compounds from Spirulina maxima microalgae and its protective effects. Afric $\mathrm{J}$ of Biotechn. 2009;8(24). BY NC) license (https://creativecommons.org/licenses/by-nc/4.0/). 